\title{
The American elm and Dutch elm disease
}

Shortly after World War I, a new disease previously unknown among elms emerged in Holland. It spread rapidly from Europe to Great Britain (1927), United States (1930), and Canada (1945), killing millions of elms. The disease known, as Dutch elm disease (DED) is a wilt disease, caused by the fungus Ophiostoma ulmi. It is transmitted from tree to tree by elm bark beetles (scolytid) vectors. Numerous attempts to control the disease have concentrated on the reduction of insect vector populations, exploitation of natural host resistance, extensive application of fungicides and integrated pest management. In spite of these efforts in Canada, the disease continues to migrate westwards threatening the elm populations in Saskatchewan and Alberta. Today there are approximately 700000 elm shade trees in cities and towns across Canada and their value exceeds $\$ 2.5$ billion dollars.

With the advance of molecular biology new, powerful tools are now available to study, in greater detail, the molecular and biochemical mechanisms of the DED pathogen, with particular reference to the mechanisms that induce host defenses. A glycoprotein has been isolated and identified such that when injected either in liquid or pellet form into the elm tree, significantly reduced the wilting symptoms of both five-year old elm seedlings and $10 \mathrm{~cm}$ diameter trees. The elicitor induces a chain of defensive reactions that prevent the rapid spread of the fungus within the vascular system of the host.

Key words: Ophiostoma ulmi, elm bark beetle vectors, induced resistance, chemical control, RFLP, mitochondrial DNA, ribosomal DNA, virus-like DNA, resistance breeding
Peu après la Première Guerre mondiale, une nouvelle maladie inconnue auparavant a commencé à apparaître parmi les ormes en Hollande. Elle s'est étendue rapidement de l'Europe à la Grande Bretagne (1927), aux États-Unis (1930), et au Canada (1945), tuent des millions d'ormes. Cette maladie désignée sous le nom de maladie hollandaise de l'orme (MHO) est une maladie fongique, causée par le champignon Ophiostoma ulmi. Elle est transmise d'arbre en arbre par un insecte vecteur (scolyte) retrouvé dans l'écorce des ormes. Plusieurs essais de contrôle de la maladie ont porté sur la réduction des populations d'insectes vecteurs, sur l'exploitation de la résistance naturelle de l'hôte, sur l'application extensive de fongicides et sur l'aménagement intégré des ravageurs. Malgré tous ces efforts déployés au Canada, la maladie continue de migrer vers l'ouest et de menacer les populations d'orme de la Saskatchewan et de l'Alberta. On compte actuellement environ 700000 ormes utilisés comme arbres d'ornement dans les villes et les cités partout au Canada et leur valeur atteint plus de 2,5 \$ milliards.

Grâce au progrès de la biologie moléculaire, de nouveaux outils efficaces sont maintenant disponibles pour étudier, avec plus de détail, les mécanismes moléculaires et biochimiques des pathogènes de la MHO, et surtout les mécanismes qui induisent des défenses chez l'hôte. Une glycoprotéine a été isolée et identifiée de telle sorte que lorsqu'elle est injectée sous forme liquide ou sous forme de pastilles dans un orme, on note une réduction marquée des symptômes de dessèchement chez les semis d'orme de 5 ans et chez les arbres de $10 \mathrm{~cm}$ de diamètre. Cette forme de protéine induit une chaîne de réactions défensives qui empêchent la propagation rapide du champignon dans le système vasculaire de l'hôte.

Mots-clés: Ophiostoma ulmi, insectes vecteurs de l'écorce d'orme, résistance induite, contrôle chimique, RLFP, ADN mitochodriale, $\mathrm{ADN}$ ribosomale, $\mathrm{ADN}$ semblable à un virus, croisement pour la résistance

\section{Introduction}

Almost 80 years ago Dutch scientists reported the dramatic appearance of a new disease on elms in Holland. The disease quickly became known as Dutch elm disease (DED). It is caused by the fungus Ophiostoma ulmi (sensus lato), and has claimed the life of millions of stately elm trees in Europe and North America. Elms, and in particular the American elm (Ulmus americana), have been an unmistakable cultural and historic landmark of the North American continent. The tree's tall and majestic growth combines beauty and grace, placing it among the most desirable shade tree in our cities and villages. Planted along boulevards and streets, their crowns span roads and houses providing clean air, coolness during hot summer days and shelter against UV radiation. The New York Times, in a February 26, 1989 article, claimed that a large tree is equivalent to five air conditioning units, playing a very important energy conservation role in our ecosystem.

Shortly after World War I, in 1918, a new, previously unknown disease of elms emerged in Holland, which caused yellowing and then wilting of leaves as well as rapid tree death.

${ }^{1}$ Faculty of Forestry, University of Toronto, Toronto, Ontario M5S 3B3.
The disease spread like a plague and traveled quickly from Europe to Great Britain (1927) and reached the United States in 1930 (Campana and Stipes 1981). Although some tree losses occurred in 1927 in England, it was the appearance of a new strain of the plague in the late 1960 s that severely decimated the elm populations (Gibbs 1981). By 1980,17 million of the 23

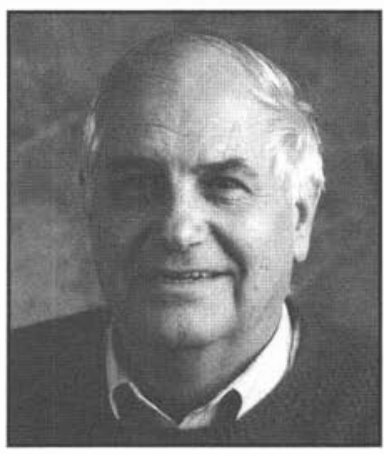
million previous existing elms had been killed in southern England, causing extensive economic, esthetic and environmental losses.

Around 1930 there were approximately 77 million elm trees in cities and towns across North America. The introduction of the disease had a devastating effect. For example, by 1976 municipalities in the northeastern United States lost $56 \%$ of their original elm population (Huntley 1982).

Equally significant, a second introduction of the disease to the North American continent at Sorell, Quebec, Canada in 1945 (Pomerleau 1981) initiated one of the largest mass destruction of trees ever witnessed, particularly when the disease fronts 
from the US and eastern Canada met to migrate westwards. Of the 77 million elms in the US prior to the disease introduction, only about 34 million survived by 1976 . In Canada the eastern provinces, New Brunswick, Quebec, and Ontario also suffered major losses. More than 600000 elms were quickly killed in Quebec and Toronto's 35000 elm tree population was rapidly reduced by $80 \%$ (Huntley 1982). Presently, the disease front has reached the elm populations of Saskatchewan and threatens those of Alberta. This situation causes great concern to private citizens as well as provincial and municipal authorities. In the prairie provinces, elms constitute the majority of shade trees in cities and villages. No other tree is better suited than the elm to withstand the harsh winter climate and urban environmental stresses in these regions, with its high winds, extreme temperatures and road salt. Therefore, the great efforts of the City of Winnipeg, for example, to save its elms through a fully integrated management program allows the City to claim itself as the City of elms. However, in spite of this, after 21 years the losses of trees due to DED went from $2.5 \%$ to near $5.0 \%$ annually in 1996 . Winnipeg's American elm population still exceeds 200000 in number. Today there are about 700000 elms as shade trees in cities and towns across Canada and their value well exceeds $\$ 2.5$ billion. The average elm tree value is based on the data given by Westwood (1991).

\section{Disease Control}

The DED fungus is mainly transmitted from tree to tree by the European elm bark beetle Scolytus multistriatus and the native elm bark beetle Hylurgopinus rufipes (Parker et al. 1947, Jin et al. 1996). Infection by DED usually occurs from late May to July while the trees are producing "early wood" in the form of large vessel cells (Pomerleau 1968, Smalley and Guries 1993). Therefore, the spring-maturating adults of the European elm bark beetles and the overwintering adults of native elm bark beetles are the most common vectors of the disease (Pomerleau 1965, Lanier 1978, Lanier and Peacock 1981, Webber 1990). In addition the fungus may also move internally from tree to tree through root grafts (Stipes and Campana 1981).

Numerous attempts to control the disease have concentrated on three processes: reducing the vector populations, namely the elm bark beetles (Lanier 1978, O'Callahan and Fairhurst 1983, Jin et al. 1996); the exploitation of natural host resistance (Ouellett and Pomerleau 1965, Holmes 1976, Lester 1978, Stipes and Campana 1981, Heybroek 1983, Smalley and Guries 1993, Ware and Miller 1997); and extensive application of fungicides (Smalley 1978, Stennes and French 1987). For the most part, these efforts have not produced the expected results of DED control (Stipes and Campana 1981, Sticklen et al. 1991).

\section{Reduction of Vector Populations}

Control of elm bark beetles via chemical insecticides still seems the preferred choice in areas of high beetle populations to reduce the inoculum potential. However, in the long run this option is not viable because of the potential negative impact of the chemical insecticides to the environment and, therefore, can only be recommended for very specific situations. Particular attention must also be given to the selection of correct application equipment, otherwise spraying is not very effective (Roy et al. 1988). The use of biological control agents such as insect parasitic (entomopathogenic) nematodes against bark beetles has not yet been exploited and awaits further development (Tomalak et al. 1989). The same is also true for the Lepidopteran BT toxins (Sticklen et al. 1991). The use of pheromone traps for vector control has great attraction from an environmental point of view. However, it did not gain the expected momentum because the results were not as anticipated (Birch $e t$ al. 1981, Sticklen et al. 1991). Lanier (1989) reported on the usefulness of elm bark beetle trap trees for control of DED. This method seems very appealing, but awaits its wider testing application and has little use in many towns and cities because trees cannot be spared for traps. Sanitation, though expensive, is imperative for a successful DED control program, by removing infected tree parts, or dead trees that harbor beetle populations as well as the perfect and imperfect stage of the fungus. If not removed and destroyed, these dead trees are a major source of inoculum. However, sanitation alone is unable to halt the progress and spread of the disease (Pomerleau 1981).

\section{Chemical Control}

The introduction of several benzimidazole systemic fungicides has prompted a number of investigations on the effect of these compounds for DED control. Of these, benomyl has been tested against $O$. ulmi (Kondo et al. 1973). Another chemically related compound known as "Arbotect 20-S" has also been reported as active against the fungus (Smalley 1978, Prosser 1998). Attempts to overcome uptake and solubility problems caused by the tree were made by injecting the chemical into the stem or by uptake experiments through the roots (Kondo 1978, Roy et al. 1980). Compartmentalization of the tree (Shigo and Campana 1977), in response to wounding during injection, solubility problems with the chemical, as well as the ability of the pathogen to develop resistance against the fungicide (Bernier and Hubbes 1990a, b, Schreiber 1993), and economic reasons did not lend themselves to very large scale application of these fungicides.

Dutch elm disease is a vascular disease. To effectively colonize its host, the DED fungus has to invade a large number of vessels and can therefore not rely on its passive travel in the transpiration stream of a limited number of vessels. It has to spread from vessel to vessel. Pit membranes are the places where this can occur. Spores have to germinate and their hyphae penetrate through the membranes. Scheffer et al. (1988) reported that sterol biosynthesis inhibitors that interfere in the hyphae formation in O. ulmi suppressed disease development in two Dutch elm clones. Among a number of chemical derivatives fenpropimorph gave the best results. The problem is that this chemical renders the tree frost sensitive. Another compound, a triazole derivative fungicide propiconazole, also known as "Alamo," has been introduced very recently for DED control. It is too soon to judge its effectiveness. Some tests appear encouraging, while others were not as successful as those were with "Arbotect 20-S" (Prosser 1998). However, the manufacturer has withdrawn this latter product from the Canadian market.

\section{Natural Host Resistance}

The prospects for developing trees with genetic resistance to DED range from uncertain (Ouellett and Pomerleau 1965, Holmes 1976) to very good (Heybroek 1993, Smalley and Guries 1993, Smalley et al. 1993, Ware and Miller 1997). Earlier efforts 
to select and breed American elms (Ulmus americana) for DED resistance were disappointing. All North American species $(U$. rubra, U. thomasii, U. alata, U. serotina, and $U$. erassifolia) are susceptible to DED. U. americana is the most susceptible. Therefore, efforts were also directed towards the development of genetic combinations from European and Asian gene pools (Smalley and Guries 1993, Smalley et al. 1993, Townsend and Santamour 1993, Sherald 1993, Ware and Miller 1997). A number of selections with superior resistance to DED were made, of which the American "Liberty" elms were the most promising. There is a problem with these selections, as the basis for their resistance is unknown to scientists and, therefore, no estimates can be made as to whether this resistance will last or not. Small changes in the genetic background of the fungal population or changes in the physiology of the host as it ages may cause loss of resistance. Indeed, the DED fungus attacks some of the formerly resistant "Liberty" elms (A.L Shigo, personal communication).

It has been debated how the DED fungus kills its host. I believe that a final solution to these problems can only be expected through application of modern methods of molecular biology by identification, isolation and subsequently directed rearrangement of genes controlling pathogen (DED) virulence and genes governing the host's defense. Once the genetic bases of pathogen virulence and host resistance have been clarified, trees with long term tolerance towards the pathogen can be developed (Hubbes 1981, 1993). This, for example, has been achieved by the Siberian elm (U. pumila), probably through natural selection.

The fact that the Asian elms show resistance to DED led to the assumption that DED originated in Asia. Recent investigations place its origin in the Himalayas (Brasier and Mehrotra 1995).

Although the development of resistant elms may satisfy the long-term strategy of DED control, effective protection of the existing elm populations in our cities and villages still remains a problem. In the past, there has been no lack of efforts to control the pathogen by biological means with the use of antagonistic microorganisms such as bacteria (Mazzone et al. 1982, Strobel and Myers 1982, Holmes and Plourde 1982, White 1982, Shi and Brasier 1986), fungi and virus particles (Hoch et al. 1985, Rogers et al. 1986, Webber 1987, Bernier et al. 1996). Some of the organisms showed promise, but their broad application as control agents has not yet been achieved. It is surprising that most of these treatments were conducted solely with the view to inhibit the fungal growth by direct antagonism, while the role of the host's defense reactions was ignored. Field observations show that some trees have the means to defend themselves successfully against the invasion of the DED pathogen by restricting the spread of the fungus in their vessels. We assume that if the mechanisms of this defense reaction could be clarified and their genetic basis understood they might well form a solid basis for disease control and resistance breeding.

\section{The Pathogen and its Strains}

In the early $1970 \mathrm{~s}$, the observation that the population of $O$. ulmi was composed of two major group of strains, the aggressive and non-aggressive group, gave rise to numerous assumptions to explain pathogenicity and virulence (Gibbs et al. 1972, Bernier 1983). The non-aggressive isolates induce slower development for foliar symptoms during the first year of infection, a difference that tends to disappear during the second year (Schreiber and Townsend 1976). Scala et al. (1997) reported similar results. Isolates of the aggressive group very quickly induce severe wilting symptoms leading to the death of the hosts.

Aggressive and non-aggressive group of isolates also differ in a wide range of morphological and physiological characters. Crossing between the two groups is believed to be rare under field conditions (Gibbs and Brasier 1973, Brasier 1977, $1979,1982)$. The aggressive group has been further subdivided in two races termed as the European (EAN) and North American (NAN) races (Brasier 1988). Initial separation of the isolates into the various sub-groups based on morphological characters was often erratic. Various well known laboratory techniques to identify isolated strains such as isozyme and protein patterns as well as restriction fragment length polymorphisms (RFLPs) and DNA fingerprinting have proven to be a very reliable approach to accurate strainal characterization (Bernier et al. 1983, Jeng and Hubbes 1983, Bates et al. 1989, Jeng et al. 1991, Hintz et al. 1991).

These methods also provide a better view into the genome (all the genes carried by a haploid germ cell) of the pathogen than earlier methods. For example, Jeng et al. (1991) showed that the size of the mitochondrial genome was $40 \%$ larger for the non-aggressive isolates than for the aggressive ones. The restriction site map of the mitochondrial genome, which is a diagram portraying a linear array of sites on the DNA segment at which specific enzymes cleave the molecule, showed that the various isolate groups differed from each other by discrete length mutations in their mitochondrial genome (Hintz et al. 1991). Based on the above criteria and some physiological characters, Brasier (1991) separated the aggressive sub-group from the non-aggressive one by classifying the former as a new species, which he named $O$. novo-ulmi, while the non-aggressive group maintained the name $O$. ulmi. Further investigations by Jeng et al. (1996) showed that the DNA sequence of the ITS1 and ITS2 region of the ribosomal gene of the aggressive and non-aggressive group display high homology but differ between each other in one DNA base pair, showing the close relatedness of the two groups. The ribosomal gene is a very important genetic marker. It is highly conserved, stable, and shows little change over long time periods. However, some of its regions (DNA stretches), such as those known as internal spacers (ITS), show some variation while others known as $18 \mathrm{~S}, 5.8 \mathrm{~S}$, or $26-28 \mathrm{~S}$ are very stable. Both are used for characterization of taxonomic units. Lately, Brasier and Mehrotra (1995) described a third species belonging to the Ophiostoma group: $O$. himal-ulmi. This species has been found on $U$. wallichiana in the Himalayas and lead to the hypothesis that the DED may have its origin in this relatively narrow geographic region.

Methods of molecular biology such as RFLPs of mitochondrial DNA (mtDNA), nuclear DNA fingerprinting and RFLPs of the ribosomal DNA (rDNA) are very sensitive tools not only for strainal characterization but also for monitoring population dynamics. Studies of strains of $O$. ulmi population from Manitoba, southeastern Saskatchewan and northern Dakota show that these populations are composed of well defined fungal strains (Hintz et al. 1993, Hubbes 1992). This observation is based on the restriction site pattern of the mtDNA. Analysis of the 
nuclear DNA fingerprinting and rDNA reveal that the nuclear type of all isolates is that of the aggressive sub-group $(O$. novo-ulmi) (Hubbes 1992). Mitochondrial DNA in O. ulmi is inherited from the mother and the nuclear DNA from the father (unpublished results from our laboratory). This means those strains carrying non-aggressive mitochondrial types and aggressive nuclear types resulted from a cross between a non-aggressive mother $(O . u l m i)$ and an aggressive father. Such strains have been reported for Manitoba (Hubbes 1992). Very recently Brasier et al. (1998) found similar strains in Europe. These observations are of great importance for the selection and breeding strategies which attempt to develop elms that in future can tolerate the disease like Siberian elms. It further indicates that under North American field conditions the number of strains is rather limited, a fact that has also been found by Brasier (1996). Changes in non-aggressive and aggressive subgroups within two populations of American elm in New England has also been reported by Houston (1991), a fact already known from Europe (Brasier 1991). The population of the nonaggressive subgroup is declining.

Furthermore, spore deficient strains of $O$. ulmi have been successfully isolated; these natural mutants lack the ability to produce conidiospores, blastospores, and ascospores. As a result of these mutants, O. ulmi is incapable of causing internal and external disease symptoms normally associated with DED (Richards et al. 1982, Richards, 1993, 1994, 1998). Spore production is of instrumental importance for the pathogen for transmittance by the elm bark beetle vector and rapid distribution within the elms vascular system. Understanding the mechanism(s) that block $O$. ulmi sporulation may be very helpful in developing methods of DED control.

\section{Fungal Metabolites as Factors of Virulence}

Although the aggressiveness of $O$. ulmi strains was initially established by inoculation experiments, the basis of this ability has not yet been precisely determined. Knowing these factors precisely would allow effective DED control strategies including the development and selection of long-term diseasetolerant American elms. Brasier and Gibbs (1976) have shown in crossing and subsequent inoculation experiments, that the $F_{1}$ generation of the fungus does not exceed the virulence of its parents. Assumptions (based on circumstantial evidence) have been made that toxins, such as cerato ulmin (CU) (Takai 1980, Richards 1993), peptidorhamno-mannan (Claydon et al. 1980, Nordin and Strobel 1981, Scheffer 1983, Scheffer et al. 1987), glycopeptides and glycoprotein elicitors (Yang et al. 1989, Hubbes 1993) may function as factors of virulence. Binz and Canevascini (1996) stated that production of extra-cellular laccase may be important for the survival of the fungus in its host. Confirmation of these compounds as factors of virulence is still waiting. For example, experiments by Bernier (1988) did not confirm previous results by Takai (1980) showing a correlation between high CU production and virulence. It appeared that the only way to prove the role of $\mathrm{CU}$ as a key factor of virulence would be the production of a number of mutants that are unable to produce the $\mathrm{CU}$ toxin. These CU negative mutants ( $\left.\mathrm{CU}^{-}\right)$should not be able to cause DED when inoculated into elms. If they do, then CU is not a major virulence factor.

Bernier (1988) produced a large number of chemically induced mutants, but none were $\mathrm{CU}^{-}$. The problem with chemically induced mutants is that the fungal genome may be altered at many more sites than those phenotypically visible. This led to efforts to identify and isolate the genes responsible for CU production (Yaguchi et al. 1993, Bowden et al. 1994, Jeng et al. 1996). Once the CU gene had been isolated a $\mathrm{CU}^{-}$mutant was created by transformation-mediated gene disruption of an aggressive strain (O. novo-ulmi). Bioassay of the $\mathrm{CU}^{-}$strain in highly susceptible elm trees indicated no difference in percent of brown streaks under the bark and percent foliar wilting. Simultaneously, Tegli and Scala (1996) obtained five $\mathrm{CU}^{-}$mutants by $\mathrm{UV}^{-}$-irradiation. In their inoculation experiments two out of the five mutants showed significant reduction in pathogenicity when compared to the wild type. However, very likely the UV-treatment affected not only genes of the CU pathway but also a number of other genes sitting at important metabolic switching points not detected by the authors.

$\mathrm{CU}^{-}$strains do occur naturally and are pathogenic (Brasier et al. 1994). This would support the view that CU is not a major virulence factor. However, there exists another possibility, i.e., that the gene(s) for pathogen virulence and CU production are located close to each other, giving the impression of one single unit. The loss of one during reproduction or by mutation would not affect the expression of the other. Recent studies by Scala et al. (1997) found higher CU levels in wilting leaves of elm seedling infected with aggressive isolates $(O$. novo-ulmi) than in those leaves of seedlings infected with nonaggressive strains (O. ulmi). Temple (1997) found that a transformed non-aggressive strain, which over- expresses $\mathrm{CU}$ production showed no alteration in virulence when compared to the parent strain. Unfortunately, no experiments were conducted to test whether the $\mathrm{CU}$ gene of the aggressive strain was expressing the correct CU protein in vivo, as tested by Scala et al. (1997). CU research is complicated, with various conflicting results being obtained by different scientists. CU may one day be shown to be a major factor in pathogen fitness and virulence.

\section{Virus-like RNA Elements for the Control of DED}

In the mean time, Brasier 1983, 1986, Hoch et al. 1985, Rogers et al. 1986, Brasier et al. 1993, Webber 1987, 1993 described the occurrence of double stranded ribosomal nucleic acid (dsRNA) particles in isolates of the aggressive strains (O. novo ulmi) and non-aggressive strains, and termed them "d-factors." One of them, the $\mathrm{d}^{2}$ factor, has been associated with reduced vigor in infected isolates (Hong et al. 1998). Work in Brasier's laboratory has been conducted to use the d-factor to control Dutch elm disease on a wide scale (Sutherland and Brasier 1997). The problem up to now has been that the d-factor is not easily transmitted from strain to strain, because not all strains are vegetatively compatible. Furthermore, the transformation of the fungus into the yeast phase, one of the main distribution phases of the fungus within the tree (Banfield 1941, Pomerleau and Mehran 1966, Pomerleau 1968) allows Ophiostoma individuals to lose deleterious d-factors (Webber 1993). Similar problems have been encountered in the US with hypovirulent strains of Cryphonectria parasitica, the causal agent of chestnut blight (Choi and Nuss 1992, Enebak et al. 1994). However, recent investigations suggest that it is the effect of induced resistance triggered by the hypovirulent strain that is responsible for the survival of chestnuts infected by chest- 
nut blight (Schafleitner and Wilhelm 1997, Ghabrial 1998). Apparently the transformation of virulent strains to hypo-virulent strains induces some changes in the physiology of hypo-virulent strains that affect the pathogen and mobilize effective defense reactions in the chestnut host.

\section{Induced Resistance for DED Control}

Our efforts here in Toronto concentrated on the defense mechanisms of elms in response to fungal infection. Cross-protection against aggressive strains of $O$. ulmi was reported in $U$. hollandica and U. americana (Scheffer et al. 1980, Hubbes and Jeng 1981). Seedlings of $U$. americana were, indeed, protected against the attack by aggressive strains when first inoculated with non-aggressive strains (Jeng et al. 1983, Duchesne 1985, Duchesne et al. 1986, Sutherland et al. 1995). We have isolated and identified a number of chemicals produced by the elm in response to the inoculations as mansonones $\mathrm{A}$, C, D, E, F and G from fungal inhibitory sapwood extract of elm seedlings treated with O. ulmi (Dumas et al. 1983, 1986; Jeng et al. 1983). Procter and Smalley (1988) also observed increased mansonone accumulation in elm inoculated with $O$. ulmi strains. Wu et al. (1989) demonstrated the toxic effect of these chemicals on the physiology and ultra-structure of the fungus. Mansonones were first reported to accumulate in elms infected with O. ulmi by Elgersma and Overeem (1971). However, these authors were unable to correlate mansonone accumulation with resistance to DED. There are several reasons why these authors overlooked the correlation. For example, they compared mansonone content between treatments on the basis of number of cuttings that were extracted rather than using a more precise unit of comparison such as dry or fresh weight. Smalley et al. (1993) and Procter et al. (1994), using a number of chemically induced mutants showing lower mansonone tolerance than the parent strains, point out that mansonones alone do not play a major role in the resistance of elms to DED. These authors could not correlate mansonone sensitivity of a number of DED fungal mutants with high virulence. This is not surprising since chemically induced mutants often are altered at many more loci (position that a gene occupies in a chromosome) than those tested and visible. Therefore, correct interpretation of the results is very difficult without knowing all the affected loci and their genetic stability.

Nevertheless, mansonone production is a very sensitive and precisely measurable process implicated in the host's reaction in response to pathogen invasion. It is definitely a part of genetically programmed sequences of host defense mechanisms in DED. Duchesne (1993) concluded that timing of expression of different mechanisms of resistance to DED is critical for both anatomical and chemical means of defense to be effective in localizing the pathogen. He bases his assumption on the faster accumulation of mansonones in $U$. pumila (Duchesne et al. 1985), the faster mansonone accumulation in U. americana inoculated with aggressive isolates, and finally on the faster barrier zone formation (Shigo and Tippet 1981) in non-host trees than in host trees inoculated with $O$. ulmi (Rioux and Ouellette 1991a, b). To isolate the mansonone-inducing factor of the DED fungus, a sensitive bioassay had to be developed. Szczegola-Derkacz (1988) showed that tissue cultures responded to $O$. ulmi inoculations with mansonone production. Autoclaved spores of the yeast phase of the DED fungus produced the same effect as living spores, indicating that the compounds triggering mansonone production are heat stable. Yang et al. (1989) demonstrated that fungal culture filtrates, cytoplasm and cell walls of $O$. ulmi contain molecules that elicit mansonone accumulation in elm calli. The culture filtrate elicitor has been purified (Yang 1991) and its structure identified (Hubbes et al., unpublished results).

When elm seedlings and elm trees $(10 \mathrm{~cm}$ in diameter) were first injected with the elicitor and then challenged with 8000 to 1 million spores of an aggressive strain per tree, the treated trees showed significant difference in wilting when compared to the control. The five-year old seedlings obtained the high spore dose, while the trees obtained the lower dose (unpublished results). A United States patent application based on the structure of the elicitor for the control of DED has been filed. The elicitor can be injected in liquid form or in pellet form into the tree. It is heat stable, has an indefinite shelf life, appears to be environmentally safe, and is easy to administer into the tree, particularly in pellet form. Field trials on the feasibility of pellet treatment as well as elicitor activity have been conducted in 1997 by a number of cities in Manitoba, Saskatchewan and Alberta. Field trials on the efficacy of the elicitor are presently being repeated in Ontario, Saskatchewan and Alberta. Investigations in our Forest Pathology laboratory on the mechanisms of induced resistance show that they follow similar complex defense reactions as those found in agricultural crops (Somssich and Hahlbrock 1998). The elicitor induces a chain of defense reactions that prevent the rapid spread of the fungus. However, the difference between agricultural crops and elm trees is that elm trees are wild type individuals with greater genetic variability and therefore show greater variations in their defense reactions. Hence, control of fungal pathogens in trees by induced resistance is a new approach to disease control and appears to be one of the few remaining options to protect the existing elm populations in our communities against DED.

Since the first appearance of DED a nagging question has emerged over and over: "Is the elm tree worth saving, and will this tree follow the doomed fate of the North American sweet chestnut? The chestnut has lost its once vast territories and other tree species have taken its place. Why then worry about losing another native tree species?" The very emotional argument against such a statement is that although the North American continent is rich in number, variety and magnificence of native trees, no tree can replace the American elm in the hearts of the people. The argument goes further in that the elm typifies, as no other tree does, the finest things in North American life. No substitute greenery, however luxurious, could hide the scars that would be left by the loss of the elm in our cities.

\section{Acknowledgements}

Part of our work has been supported by NSERC, City of Winnipeg, Province of Manitoba, Province of Saskatchewan, Coalition to Save the Elms, University of Toronto. Many thanks also to Mike Allen, Chief Forester of the City of Winnipeg, for reviewing the manuscript.

\section{References}

Banfield, W.M. 1941. Distribution by the sap stream of spores of three fungi that induce vascular wilt disease of elm. J. Agic. Res. 62(11): 637-681.

Bates, M.R., K.W., Buck and C.M. Brasier. 1989. The use of nucle- 
ar and mitochondrial DNA polymorphisms to investigate the population genetics, epidemiology and evolution of Ophiostoma ulmi the causative agent of Dutch elm disease. J. Cell. Bioch. 13: 112.

Bernier, L. 1983. Relationships between isoenzymes, cultural characters, and pathogenicity in Ceratocystis ulmi (Busim.) C. Moreau. M.Sc.F. thesis, Department of Forestry, University of Toronto.

Bernier, L. 1988. Induction, characterization and mapping of mutations in Ophiostoma ulmi, the causal agent of Dutch elm disease. Ph.D. thesis, Department of Forestry, University of Toronto.

Bernier, L. and M. Hubbes. 1990a. Mutations in Ophiostoma ulmi induced by $\mathrm{N}$-methyl-N'-nitro-N-nitrosoguanidine. Can. J. Bot. 68: 225-231.

Bernier, L. and M. Hubbes. 1990b. Meiotic analysis of induced mutations in Ophiostoma ulmi. Can. J. Bot. 68: 232-235.

Bernier L., R.S. Jeng and M. Hubbes. 1983. Differentiation of aggressive and nonaggressive strains of Ceratocystis ulmi by polyacrylamide gel electrophoresis of intramycelial enzymes. Mycotaxon 17: 456-472.

Bernier, L., D. Yang, G.B. Ouellette and M. Dessureault. 1996. Assessment of Phaeotheca dimorphospora for biological control of the Dutch elm disease pathogens, Ophiostoma ulmi and O. novo-ulmi. Plant Pathol. 45(4): 609-617.

Binz, T. and G. Canevascini. 1996. Differential production of extracellular laccase in the Dutch elm disease pathogens Ophiostoma ulmi and O. novo-ulmi. Mycol. Res. 100(9): 1060-1064.

Birch, M.C., T.D. Paine and J.C. Miller. 1981. Effectiveness of pheromone mass-trapped of the smaller European elm bark beetle. Calif. Agric. 35(1-2): 6-7.

Bowden, C.G., W.E. Hintz, R. Jeng, M. Hubbes and P.A. Horgen. 1994. Isolation and characterization of the cerato-ulmin toxin gene of the Dutch elm disease pathogen, Ophiostoma ulmi. Curr. Genet. 25: 323-329.

Brasier, C.M. 1977. Inheritance of pathogenicity and cultural characters in Ceratocystis ulmi: Hybridization of protoperithecial and nonaggressive strains. Trans. Brit. Mycolog. Soc. 68: 45-52.

Brasier, C.M. 1979. Dual origin of recent Dutch elm disease outbreaks in Europe. Nature 281: 78-80.

Brasier, C.M. 1982. Occurrence of three subgroups with Ceratocystis ulmi. In E.S. Kondo, Y. Hiratsuka and W.B.G. Denyer (eds.). Proceedings of the Dutch elm disease symposium and workshop, Winnipeg, Manitoba, October 5-9, 1981. pp. 298-321. Manitoba Department of Natural Resources, Manitoba, Canada.

Brasier, C.M. 1983. A cytoplasmically transmitted disease of Ceratocystis ulmi. Nature 305: 220-223.

Brasier, C.M. 1986. The d-factor in Ceratocystis ulmi: its biological characteristics and implication for Dutch elm disease. In K.W. Buck (ed.). Fungal Virology. pp. 177-208. CRC Press, Florida. Brasier, C.M. 1988. Rapid changes in genetic structure of epidemic populations of Ophiostoma ulmi. Nature 332: 538-541.

Brasier, C.M. 1991. Ophiostoma novo-ulmi sp. nov., causative agent of current Dutch elm disease pandemics. Mycopathologia 115: 151-161.

Brasier, C.M. 1996. Low genetic diversity of Ophiostoma novo-ulmi population in North America. Mycologia 88(6): 951-964.

Brasier, C.M., M.R. Bater, N.W. Charter and K.W. Buck. 1993. DNA polymorphism, perithecial size and molecular aspects of D factors in Ophiostoma ulmi and O. novo-ulmi. In M.B. Sticklen and J.L. Sherald (eds.). Dutch Elm Disease Research: Cellular and Molecular Approaches. pp. 308-321. Springer-Verlag, Berlin, New York. Brasier, C.M. and J.N. Gibbs. 1976. Inheritance of pathogenicity and cultural characters in Ceratocystis ulmi: Hybridization of aggressive and nonaggressive strains. Ann. Appl. Biol. 83: 31-37.

Brasier, C.M., S. Kirk and S. Tegli. 1994. Naturally occurring non cerato-ulmin producing mutants of Ophiostoma novo-ulmi are pathogenic but lack of aerial mycelium. Mycol. Res. 99: 436-440. Brasier, C.M., S.A. Kirk, N.D. Pipe and K.W. Buck. 1998. Rare interspecific hybrids in natural populations of the Dutch elm disease pathogens Ophiostoma ulmi and O. novo-ulmi. Mycol. Res. 102(1): 45-57.

Brasier, C.M. and M.D. Mehrotra. 1995. Ophiostoma himalulmi sp. nov., a new species of Dutch elm disease fungus endemic to the Himalayas. Mycol. Res. 99(2): 205-215.

Campana, R.J. and R.J. Stipes. 1981. Dutch elm disease in North America with particular reference to Canada: Success or failure of conventional control methods. Can. J. Plant Pathol. 3: 252-259.

Choi, G.H. and D.L. Nuss. 1992. Hypovirulence of chestnut blight fungus conferred by an infectious viral cDNA. Science 257: 800-803. Claydon, N., D.M. Elgersma and J.F. Grove. 1980. The phytotoxicity of some phenolic metabolic products of Ophiostoma ulmi to Ulmus species. Nether. J. of Plant Pathol. 86: 229-237.

Duchesne, L.C. 1985. Phytoalexin accumulation of resistance to Dutch elm disease. M.Sc.F. thesis, Department of Forestry, University of Toronto. $111 \mathrm{p}$.

Duchesne, L.C. 1993. Mechanisms of resistance: can they help save susceptible elms? In M.B. Sticklen and J.L. Sherald (eds.). Dutch Elm Disease Research: Cellular and Molecular Approaches. pp. 239-254. Springer-Verlag, Berlin, New York

Duchesne, L.C., M. Hubbes and R.S. Jeng. 1986. Mansonone E and $\mathrm{F}$ accumulation in Ulmus pumila resistant to Dutch elm disease. Can. J. For. Res. 16: 410-412

Duchesne, L.C., R.S. Jeng and M. Hubbes. 1985. Accumulation of phytoalexins in Ulmus americana in response to injection by a nonaggressive and an aggressive strain of Ophiostoma ulmi. Can. J. Bot. 63: 678-680.

Dumas, M.T., G.M. Strunz, M. Hubbes and R.S. Jeng. 1983. Isolation and identification of six mansonones form Ulmus americana infected with Ceratocystis ulmi. Experientia 39: 1089-1090.

Dumas, M.T., G.M. Strunz, M. Hubbes, and R.S. Jeng. 1986. Inhibition of Ceratocystis ulmi by mansonones A, C, D, F, and G isolated from Ulmus americana. Europ. J. For. Pathol. 16: 217-222.

Elgersma, D.M. and J.C. Overeem. 1971. The relation of mansonones to resistance against Dutch elm disease and their accumulation as induced by several agents. Neth. J. Plant Pathol. 79: 218-220.

Enebak, S.A., W.L. MacDonald, and B.I. Hillman. 1994. Effect of dsRNA associated with isolates of Cryphonectria parasitica from the central Appalachians and their relatedness to other dsRNAs from North America and Europe. Phytopathology 84: 528-534.

Ghabrial, S.A. 1998. Origin, adaptation and evolutionary pathways of fungal viruses. Virus Genes 16(1): 119-131.

Gibbs, J.N. 1981. Dutch elm disease. In R.J. Stipes and R.J. Campana (eds.). Compendium of elm diseases. p. 7. Am. Phytopathol. Soc. St. Paul, MN.

Gibbs J.N. and C.M. Brasier. 1973. Correlation between cultural characters and pathogenicity in Ceratocystis ulmi isolates form Britain, Europe and North America. Nature 241: 381-383.

Gibbs, J.N., H.M. Heybroek and F.W. Holmes. 1972. Aggressive strain of Ceratocystis ulmi in Britain. Nature 236: 121-122.

Heybroek, H.M. 1983. Resistant elms for Europe. In A. Burdekin (ed.). Research on Dutch elm disease in Europe. pp. 108-113. Forestry Commission Bull. 60, London.

Heybroek, H.M. 1993. Why bother about the elm? In M.B. Sticklen and J.L. Sherald (eds.). Dutch Elm Disease Research: Cellular and Molecular Approaches. pp. 1-8. Springer-Verlag, Berlin, New York.

Hintz, W.E., R.S. Jeng, M. Hubbes and P.A. Horgen. 1991. Three populations of Ophiostoma ulmi (aggressive subgroup) as uncovered by mitochondrial DNA restriction-site mapping and nuclear DNA fingerprinting. Exp. Mycol. 15: 316-325.

Hintz, W.E., R.S. Jeng, M. Hubbes and P.A. Horgen. 1993. A genetic survey of the pathogen fungus Ophiostoma ulmi at a Dutch elm disease front in western Canada. Genome 36: 418-426.

Hoch, J.G., S.M. Tavantzis, R.J. Campana and S.L. Anagnostakis. 1985. Evaluation of the presence of double-stranded RNA in Ceratocystis ulmi. Can. J. Bot. 63: 297-300. 
Holmes, F.W. 1976. While Dutch elm disease continues to spread, natural selection in wild elms may save the species from extinction. Horticulture 54(1): 72-78.

Holmes, F.W. and D.F. Plourde. 1982. Use of Pseudomonas syringae in naturally infected elms along streets. In E.S. Kondo, Y. Hiratsuka and W.B.G. Denyer (eds.). Proceedings of the Dutch elm disease symposium and workshop, Winnipeg, Manitoba, October 5-9, 1981. pp. 62-70. Manitoba Department of Natural Resources, Manitoba, Canada.

Hong, Y.G., T.E. Cole, C.M. Brasier and K.W. Buck. 1998. Novel structures of two virus-like RNA elements from a diseased isolate of the Dutch elm disease fungus, Ophiostoma novo-ulmi. Virology $242: 80-89$.

Houston, D.R. 1991. Changes in nonaggressive and aggressive subgroups of Ophiostoma ulmi within two populations of American elm in New England. Plant Dis. 75(7): 720-722.

Hubbes, M. 1981. Discussion. In R.J. Campana and R.J. Stipes. Dutch elm disease in North America with particular reference to Canada: Success or failure of conventional control methods. pp. 258-259. Can. J. Plant Pathol. 3: 252-259.

Hubbes, M. 1992. Identification of wild type isolates of Ophiostoma ulmi from Manitoba by mitochondrial DNA restriction fragment length polymorphisms and ribosomal DNA patterns. Report submitted to Manitoba Natural Resources.

Hubbes, M. 1993. Mansonones, elicitors and virulence. In M.B. Sticklen and J.L. Sherald (eds.). Dutch Elm Disease Research: Cellular and Molecular Approaches. pp. 208-215. Springer-Verlag, Berlin, New York.

Hubbes, M. and R.S. Jeng. 1981. Aggressiveness of Ceratocystis ulmi strains and induction of resistance in Ulmus americana. Europ. J. For. Pathol. 11: 257-264.

Huntley, G.D. 1982. The elm - a resurgent resource or a persistent problem? In E.S. Kondo, Y. Hiratsuka and W.B.G. Denyer (eds.). Proceedings of the Dutch elm disease symposium and workshop, Winnipeg, Manitoba, October 5-9, 1981. pp. 103-111. Manitoba Department of Natural Resources, Manitoba, Canada.

Jeng, R.S., A.C. Alfenas, M. Hubbes and M. Dumas. 1983. Presence and accumulation of fungitoxic substances against Ceratocystic ulmi in Ulmus americana: possible relation to induced resistance. Europ. J. For. Pathol. 13: 261-178.

Jeng, R.S., L.C. Duchesne, M. Sabourin and M. Hubbes. 1991. Mitochondrial DNAs restriction fragment length polymorphisms of aggressive and non-aggressive isolates of Ophiostoma ulmi. Mycol. Res. 95(5): 537-542.

Jeng, R.S., W.E. Hintz, C.G. Bowden, P.A. Horgen and M. Hubbes. 1996. A comparison of the nucleotide sequence of the cerato-ulmin gene between aggressive and non-aggressive isolates of Ophiostoma ulmi sensu lato, the causal agent of Dutch elm disease. Current Genetics 29(2): 168-173.

Jeng R.S. and M. Hubbes. 1983. Identification of aggressive and nonaggressive strains of Ceratocystis ulmi by polyacrylamide gradient gel electrophoresis of intramycelial proteins. Mycotaxon 17: 445-455.

Jin, H., G.R.B. Webster, N.J. Holliday, P.A. Pines and A.R. Westwood. 1996. An elm bark beetle bioassay for residual efficacy of chlorpyrifos and cypermethrin used for the control of Dutch elm disease in Manitoba. J. Environ. Sci. Health Part B 31(4): 751-761. Kondo, E.S. 1978. Scope and limitations of carbendazim phosphate injections in Dutch elm disease control. J. Arboric. 4: 86-88. Kondo, E.S., D.N. Roy and E. Jorgensen. 1973. Salts of methyl2-benzimidazole carbamate (MBC) and assessment of their potential in Dutch elm disease control. Can. J. For. Res. 3: 548-555.

Lanier, G.N. 1978. Vectors. In W.A. Sinclair and R.J. Campana (eds.). Dutch elm disease: perspectives after 60 years. pp. 13-17. Cornell Univ. Agric. Exp. Stn. Search (Agriculture) 8.

Lanier, G.N. 1989. Trap trees for control of Dutch elm disease. J. Arboric. 15: 105-111.
Lanier, G.N. and J.W. Peacock. 1981. Vectors of the pathogen. In R.J. Stipes and R.J. Campana (eds.). Compendium of elm diseases. pp. 14-16. Am. Phytopathol. Soc. St. Paul, MN.

Lester, D.T. 1978. Control tactics in research and practice: V. Exploiting host variation. In W.A. Sinclair and R.J. Campana (eds.). Dutch elm disease: perspectives after 60 years. pp. 39-42. Cornell Univ. Agric. Exp. Stn. Search (Agriculture) 8.

Mazzone, H.M, J. Kluck, N.R. Dubois and R. Zerilll. 1982. Dutch elm disease control with biological agents or their metabolites. In E.S. Kondo, Y. Hiratsuka and W.B.G. Denyer (eds.). Proceedings of the Dutch elm disease symposium and workshop, Winnipeg, Manitoba, October 5-9, 1981. pp. 36-45. Manitoba Department of Natural Resources, Manitoba, Canada.

Nordin, J.H. and G.A. Strobel. 1981. Structural and immunochemical studies on the phytotoxic peptidorhamnomannan of $\mathrm{Cer}$ atocystis ulmi. Plant Physiol. 1208-1213.

O'Callaghan, D.P. and C.P. Fairhurst. 1983. Evaluation of the trap tree technique for the control of Dutch elm disease in northwest England. In D.A. Burekin (ed.). Research on Dutch elm disease in Europe pp. 23-28. Forestry Commission Bull. 60, London.

Ouellette, C.E. and R. Pomerleau. 1965. Recherches sur la Résistance de L'Orme D'Amérique au Ceratocystis ulmi. Can. J. Bot. 43: 85-97.

Parker, K.G., D.L. Collins, L.J. Tyler, D.P. Connola, W.E. Ozard and H. Dietrich. 1947. The Dutch elm disease - association of Ceratostomella ulmi with Scolytus multistriatus, its advance into new areas, and control of the disease. Cornell Univ. Agr. Exp. Stn. Memoir 275. 44 p.

Pomerleau, R. 1965. Seasonal transmission of the elm disease by Hylurgopinus rufipes in Quebec. Can. J. Bot. 43: 1592-1595.

Pomerleau, R. 1968. Progression et localisation de l'infection par le Ceratocystis ulmi dans l'orme d'Amérique. Phytopath. Z. 63: 301-327. Pomerleau, R. 1981. Dutch elm disease in Canada. In R.J. Stipes and R.J. Campana (eds.). Compendium of elm diseases. pp. 8-9. Am. Phytopathol. Soc. St. Paul, MN.

Pomerleau, R. and R. Mehran. 1966. Distribution of spores of Ceratocystis ulmi labeled with phosphorus-32 in green shoots and leaves of Ulmus americana. Naturaliste Can. 93: 577-582.

Proctor, R.H., R.P. Guries and E.B. Smalley. 1994. Lack of association between tolerance to the elm phytoalexin mansonone $\mathrm{E}$ and virulence in Ophiostoma novo-ulmi. Can. J. Bot. 72: 1355-1364. Procter, R.H. and E.B. Smalley. 1988. Localized accumulation of mansonones $\mathrm{E}$ and $\mathrm{F}$ in elms following inoculations with Ophiostoma ulmi. Can. J. Plant Pathol. 10: 371. (Abstract).

Prosser, T. 1998. One company's success against Dutch elm disease. Tree Care Industry June 1998: 60-64.

Richards, W.C. 1993. Cerato-ulmin: A unique wilt toxin of instrumental significance in the development of Dutch elm disease. In M.B. Sticklen and J.L. Sherald (eds.). Dutch Elm Disease Research: Cellular and Molecular Approaches. pp. 89-151. Springer-Verlag, Berlin, New York.

Richards, W.C. 1994. Nonsporulation in the Dutch elm disease fungus, Ophiostoma ulmi: evidence for control by a single nuclear gene. Can. J. Bot. 72: 461-467.

Richards, W.C. 1998. Novel spore deficient mutants of the dimorphic fungal plant pathogen, Ophiostoma ulmi. Crop Health Unlimited Horizons. CPS/APS joint meeting, July 6-7/97. Winnipeg, Manitoba. Phytopathology 88: No 9 (Supplement), 1998 S113.

Richards, W.C., S. Takai, D. Lin, Y. Hiratsuka and S. Asina. 1982. An abnormal strain of Ceratocystis ulmi incapable of producing external symptoms of Dutch elm disease. Europ. J. For. Pathol. 12: 193-202. Rioux, D. and G.B. Ouellette. 1991a. Barrier zone formation in host and non-host trees inoculation with Ophiostoma ulmi. 1. Anatomy and Histochemistry. Can. J. Bot. 69: 2055-2073.

Rioux, D. and G.B. Ouellette. 1991b. Barrier zone formation in host and non-host trees inoculation with Ophiostoma ulmi. 2. Ultrastructure. Can. J. Bot. 69: 2074-2083. 
Rogers, H.J., K.W. Buck and C.M. Brasier. 1986. Transmission of double-stranded RNA and a disease factor in Ophiostoma ulmi. Plant Pathol. 35: 277-287.

Roy, D.N., J.R. Purdy and P. Ayyamperumal. 1980. Distribution of methyl benzimidazol-2-yl carbamate phosphate in elm: effects of chemical properties and formulation variables. Can. J. For. Res. 10: 143-151.

Roy, D.N., J.R. Purdy, P.A. Perumal and J.K. Grace. 1988. Effect of application equipment on the distribution of chlorpyrifos applied for Dutch elm disease vector control. Proc. Entomol. Soc. Ont. 119: 63-68.

Scala, A., M. Pattuelli, L. Coppola, M. Guastini, S. Tegli, G. DelSorbo, Mittempergher, L. and Scala, F. 1997. Dutch elm disease progression and quantitative determination of cerato-ulmin in leaves, stems and branches of elms inoculated with Ophiostoma novoulmi and O. ulmi. Physiol. Mol. Plant Pathol. 50: 349-360.

Schafleitner, R. and E. Wilhelm. 1997. Effect of virulent and hypovirulent Cryphonectria parasitica (Murr.) Barr on the intercellular pathogen related proteins and on total protein pattern of chestnut (Castanea sativa Mill.). Physiol. Mol. Plant Pathol. 51: 323-332.

Scheffer, R.J. 1983. Toxins in Dutch elm disease. In D.A. Burekin (ed.). Research on Dutch elm disease in Europe. pp. 82-85. Forestry Commission Bull. 60. London.

Scheffer, R.J., A.C. Brakenhoff, A. Kerkenaar and D.M. Elgersma. 1988. Control of Dutch elm disease by the sterol biosynthesis inhibitors fenpropimorph and fenpropidin. Neth. J. Plant Pathol. 94: 161-173.

Scheffer, R.J., H.M. Heybroek and D.M. Elgersma. 1980. Symptom expression in elms after inoculation with combinations of an aggressive and non-aggressive strain of Ophiostoma ulmi. Neth. J. Plant Pathol. 86: 315-317.

Scheffer, R.J., J.I. Liem and D.M. Elgersma. 1987. Production in vitro of phytotoxic compounds by non-aggressive and aggressive isolates of Ophiostoma ulmi, the Dutch elm disease pathogen. Physiol. Molec. Plant Pathol. 30: 321-325.

Schreiber, L.R. 1993. An old problem; a new approach.In M.B. Sticklen and J.L. Sherald (eds.). Dutch Elm Disease Research: Cellular and Molecular Approaches. pp. 51-59. Springer-Verlag, Berlin, New York. Schreiber, L.R. and A.M. Townsend. 1976. Variability in aggressiveness, recovery and cultural characteristics of isolates of Ceratocystis ulmi. Phytopathology 66: 239-244.

Sherald, J. 1993. Demands and opportunities for selecting disease resistant elms. In M.B. Sticklen and J.L. Sherald (eds.). Dutch Elm Disease Research: Cellular and Molecular Approaches. pp. 60-68. Springer-Verlag, Berlin, New York.

Shi, J.L. and C.M. Brasier. 1986. Experiments on the control of Dutch elm disease by injection of Pseudomonas species. Eur. J. For. Pathol. 16: 280-292.

Shigo, A.L. and R. Campana. 1977. Discoloured and decayed wood associated with injection wounds in American elm. J. Arboric. 3: $230-235$.

Shigo. A.L. and J.T. Tippet. 1981. Compartmentalization of American elm tissues infected by Ceratocystis ulmi. Plant Disease 65: 715-718. Smalley, E.B. 1978. Control tactics in research and practices: IV. Systemic chemical treatments of trees for protection and therapy. In W.A. Sinclair and R.J. Campana (eds.). Dutch elm disease: perspectives after 60 years. pp. 34-39. Cornell Univ. Agric. Exp. Stn. Search (Agriculture) 8 .

Smalley, E.B. and R.P. Guries. 1993. Breeding elms for resistance to Dutch elm disease. Annu. Rev. Phytopathol. 31: 325-352.

Smalley, E.B., R.P. Guries and D.T. Lester. 1993. American liberty elms and beyond: going from the impossible to the difficult. In M.B. Sticklen and J.L. Sherald (eds.). Dutch Elm Disease Research: Cellular and Molecular Approaches. pp. 26-45. Springer-Verlag, Berlin, New York.

Smalley, E.B., K.F. Raffa, R.H. Proctor and K.D. Klepzig. 1993. Tree responses to infection by species of Ophiostoma and Cerato- cystis. In M.J. Wingfield, K.A. Seifert and J.F. Webber (eds.). Ceratocystis and Ophiostoma, Taxonomy, ecology, and pathogenicity. pp. 207-218. APS, St. Paul, Minnesota.

Somssich, I.E. and K. Hahlbrock. 1998. Pathogen defence in plants - a paradigm of biological complexity. Trends Plant Sci. 3(3): 86-90.

Stennes, M.A. and D.W. French. 1987. Distribution and retention of thiabendazoic hypophosphite and carbendazim phosphate injected into mature American elms. Phytopathology 77: 707-712.

Sticklen, M.B., M.G. Bolyard, R.K. Hajela and L.C. Duchesne. 1991. Molecular and cellular aspects of Dutch elm disease. Phytoprotection 72: 1-13.

Stipes R.J. and R.J. Campana (eds.). 1981. Compendium of elm disease. Amer. Phytopathol. Soc., St. Paul. MN.

Strobel, G.A. and D. Myers. 1982. Bacterial antagonism as a strategy for the treatment of Dutch elm disease. In E.S. Kondo, Y. Hiratsuka and W.B.G. Denyer (eds.). Proceedings of the Dutch elm disease symposium and workshop, Winnipeg, Manitoba, October 5-9, 1981. pp. 46-61. Manitoba Department of Natural Resources, Manitoba, Canada.

Sutherland, M.L. and C.M. Brasier. 1997. A comparison of thirteen d-factors as potential biological control agents of Ophiostoma novo-ulmi. Plant Pathol. 46: 680-693.

Sutherland, M.L., L. Mittempergher and C.M. Brasier. 1995. Control of Dutch elm disease by induced host resistance. Eur. J. For. Pathol. 25: 307-318.

Szczegola-Derkacz, M. 1988. Induction of mansonones by Ophiostoma ulmi in tissue cultures of Ulmus americana and Ulmus pumila. M.Sc.F. thesis, Department of Forestry, University of Toronto. Takai, S. 1980. Relationship of the production of the toxin, ceratoulmin, to synnemata formation, pathogenicity, mycelial habit, and growth of Ceratocystis ulmi isolates. Can. J. Bot. 58: 658-662.

Tegli, S. and A. Scala. 1996. Isolation and characterization of noncerato-ulmin producing laboratory induced mutants of Ophiostoma novo-ulmi. Mycol. Res. 100(6): 661-668.

Temple, B.O. 1997. The biological role of the hydrophobin ceratoulmin in the life history of Ophiostoma ulmi and O. novo-ulmi. M.Sc.F. thesis, Department of Botany, University of Toronto. 133 p. Tomalak. M., H.E. Welch and T.D. Galloway. 1989. Nematode parasites of bark beetles (Scolytidae) in southern Manitoba, with descriptions of three new species of Sulphuretylenchus Rühm (Nematoda: Allantonematidae). Can. J. Zool. 67: 2497-2505.

Townsend, A.M. and F.S. Santamour, Jr. 1993. Progress in the development of disease-resistant elms. In M.B. Sticklen and J.L. Sherald (eds.). Dutch elm disease research: Cellular and molecular approaches. pp. 46-50. Springer-Verlag New York, Inc.

Ware, G. and F. Miller. 1997. Developing better elms. American Nurseryman August 15, 1997: 44-51.

Webber, J.F. 1987. Influence of the $\mathrm{d}^{2}$ factor on survival and infection by the Dutch elm disease pathogen Ophiostoma ulmi. Plant Pathol. 36: 531-538.

Webber, J.F. 1990. Relative effectiveness of Scolytus scolytus, $S$. multistriatus and S. kirschi as vectors of Dutch elm disease. Eur. J. For. Pathol. 20: 184-192.

Webber, J.F. 1993. D factors and their potential for the control of Dutch elm disease. In M.B. Sticklen and J.L. Sherald (eds.). Dutch elm disease research: Cellular and molecular approaches. pp. 322-332. Springer-Verlag New York, Inc.

Westwood, A.R. 1991. A cost benefit analysis of Manitoba's integrated Dutch elm disease management program 1975-1990. Proc. Entomol. Soc. Manitoba 47: 44-59.

White, J.C. 1982. An industrial approach to biological control of Dutch elm disease. In E.S. Kondo, Y. Hiratsuka and W.B.G. Denyer (eds.). Proceedings of the Dutch elm disease symposium and workshop, Winnipeg, Manitoba, October 5-9, 1981. pp. 71-77. Manitoba Department of Natural Resources, Manitoba, Canada.

Wu, W.D., R.S. Jeng and M. Hubbes. 1989. Toxic effect of elm 
phytoalexin mansonones on Ophiostoma ulmi, the causal agent of Dutch elm disease. Europ. J. For. Pathol. 19: 343-357.

Yaguchi, M., M. Pusztai-Carey, C. Roy, W.K. Surewicz, P.R. Carey, K.J. Stevenson, W.C. Richards and S. Takai. 1993. Amino acid sequence and spectroscopic studies of Dutch elm disease toxin, cerato-ulmin. In M.B. Sticklen and J.L. Sherald (eds.). Dutch elm disease research: Cellular and molecular approaches. pp. 152-170.
Springer-Verlag New York, Inc.

Yang, D. 1991. Isolation, identification and characterization of phytoalexin elicitors from Ophiostoma ulmi. Ph.D. thesis, Department of Forestry, University of Toronto.

Yang, D., R.S. Jeng and M. Hubbes. 1989. Mansonone accumulation in elm callus induced by elicitors of Ophiostoma ulmi, and general properties of elicitors. Can. J. Bot. 67: 3490-3497. 